
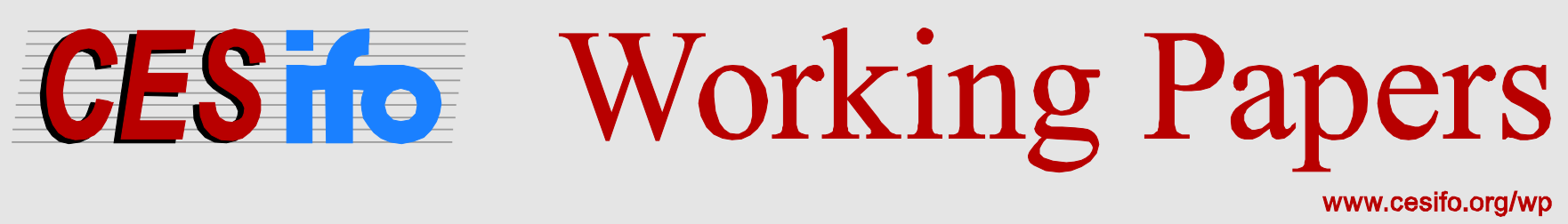

\title{
External Debt and International Trade: Another Mismatch
}

\author{
Eiji Fujii \\ CESIFO WORKING PAPER NO. 5519 \\ CATEgOry 7: MONETARY POLICY AND INTERNATIONAL FinANCE \\ ORIGINAL VERSION: SEPTEMBER 2015 \\ THIS VERSION: APRIL 2016 \\ An electronic version of the paper may be downloaded \\ - from the SSRN website: \\ - from the RePEc website: \\ - from the CESifo website: \\ WWW.SSRN.com \\ www.RePEc.org \\ www.CESifo-group.org/wp
}




\title{
External Debt and International Trade: Another Mismatch
}

\begin{abstract}
Currency mismatch makes a debtor country suffer from domestic depreciation by magnifying the burden of its external debt. Because external debt can be repaid by exporting more than importing, a crucial channel for inducing recovery is net exports. However, the argument that domestic depreciation correspondingly boosts net exports is not warranted if currency compositions differ substantially between debt and trade. This study examines the association between the debt revaluation and trade competitiveness gain effects of exchange rate fluctuations for middle- and low-income countries. The empirical results suggest that currencycompositional discord between debt and trade has significant welfare implications.
\end{abstract}

JEL-Code: F340, F310.

Keywords: currency mismatch, effective exchange rate, external debt, original sin, net export.

\author{
Eiji Fujii \\ School of Economics \\ Kwansei Gakuin University \\ 1-155 Uegahara Ichiban-cho, Nishinomiya \\ Japan - Hyogo 662-8501 \\ efujii@kwansei.ac.jp
}

This version: April 19, 2016

I am grateful to Mahir Binici for helpful comments and suggestions. I would also like to thank Frank Westermann, Andreas Steiner, Michel Beine, Mark Spiegel, Xingwang Qian, Etienne Farvaque, and participants of the CESifo workshop on International Currency Exposure and the 9th Workshop of Methods in International Finance Network for comments. All remaining errors are solely mine. This research was supported by JSPS KAKENHI Grant Number 25285087. 


\section{Introduction}

In theory, international borrowing and lending is beneficial for all parties. When inter-temporal trade is immune to market segmentation by political borders, it can achieve more efficient resource allocation. However, in reality, the world asymmetrically consists of diverse countries with various currencies. To realize the benefit, borrowers and lenders separated by national borders must first concur on the currency in which their contracts will be denominated.

When debt is denominated in currencies with a high devaluation risk, investors demand a premium. International debt, unsurprisingly, tends to be denominated in currencies with prominent credibility and thick markets, represented most notably by the US dollar (USD). As a consequence, many countries, especially less developed ones, borrow abroad typically in foreign currencies, a phenomenon referred to as the "original sin.” Because their assets are more likely to be denominated in domestic currencies, currency mismatches exist between the two sides of the balance sheets. The original sin and currency mismatch have drawn significant attention in academic and policy circles as important factors contributing to recurrent financial crises around the globe. ${ }^{1}$

For emerging economies, currency mismatch is a double-edged sword (Ranciere, Tornell, and Vamvakidis, 2010a). Although currency mismatch can reduce borrowing constraints to boost economic growth, it also increases vulnerability to exchange rate variability. A debtor country lacking foreign currency assets that provide a buffer suffers severely from depreciation of its domestic currency as it magnifies burden of its

\footnotetext{
1 See, for instance, Hausmann and Panizza (2003), Goldstein and Turner (2004), Eichengreen, Hausmann, and Panizza (2007), and Ranciere, Tornell, and Vamvakidis (2010a).
} 
external debt liabilities. ${ }^{2}$ In such circumstances, a key channel remaining for debt-laden countries to induce recovery is international trade. Because external debt can be repaid by exporting more than importing, it is vital to boost net exports to alleviate this problem. $^{3}$

In general, domestic depreciation makes a country’s exports more competitive and imports more expensive, boosting net exports as a result. Nevertheless, the argument that domestic depreciation will boost net exports in a corresponding fashion to debt revaluation is unwarranted if currency composition differs substantially between external debt and international trade. ${ }^{4}$ This currency-compositional discord between external debt and international trade-referred to as "another mismatch" — is the theme of this study.

The following example may help depict the issue. Consider Mexico and Liberia. These countries have external debt denominated primarily in USD in approximate equal proportions. The decade average indicates that approximately $76 \%$ of the long-term public and publicly guaranteed (PPG) external debt of Mexico is denominated in USD. The corresponding share for Liberia is similar at $74 \%{ }^{5}$ In contrast, the shares of the United States as their export destination (import origin) differ strikingly—at

\footnotetext{
${ }^{2}$ Hereafter, "depreciation" is used to refer to a decline in a currency value regardless of whether it occurs as a market adjustment of a floating rate or devaluation of a fixed rate by authority.

${ }^{3}$ In general, foreign exchange reserves are the primary buffer assets for external PPG debt. However, as the notion of currency mismatch indicates, less developed countries typically do not possess sufficient reserves to cover their external debt. In such circumstances, net exports assume an important role in partially offsetting the debt revaluation effects of domestic depreciation. In the empirical exercise in section 4, we incorporate the reserves to GDP ratio to ensure robustness of the results.

${ }^{4}$ See the chapter by Sokolova in this volume for issues related to the choice of currency in international trade.

${ }^{5}$ The figures are the averages for 2003-2012.
} 
approximately 82\% (52\%) for Mexico and only 10\% (1\%) for Liberia. Thus, depreciation of the same magnitude of the Mexican peso and Liberian dollar against the USD, although similarly increasing the external debt burden of the two countries, is likely to have different effects on their international trade. An extent of domestic depreciation that may significantly vitalize Mexican net exports will not be nearly as igniting for Liberian net exports.

When the currency compositions are accordant between debt and trade, the effects of domestic depreciation in terms of an increasing debt burden are more likely to be offset, at least partly, by a subsequent increase in net exports. In a sense, having the “right” currency compositions to denominate a country’s external debt may be deemed as a built-in alleviation mechanism. Thus, we hypothesize that the debt-trade currency compositional mismatch can have important welfare implications for borrowing countries.

In this study, we first investigate recent trends in currency denominations of external debt of middle-income countries (MICs) and low-income countries (LICs). Further, using data on debt-denominating currency compositions and nominal exchange rates, we construct debt-weighted effective exchange rate (DEER) indices to examine their association with the trade-weighted real effective exchange rate (TREER) series. The DEER-TREER correlation depicts the interaction between the two effects arising from domestic depreciation: the revaluation effect on external debt and the trade competitiveness gain effect. Furthermore, using growth regressions, we test whether variations in the extent of debt-trade currency discord significantly determine cross-country differences in growth performance.

Our chief findings are as follows. For the long-term PPG debt of MICs and LICs, 
we find little evidence of the alleviation of the original sin during the past three decades. Overall, their external debt continues to be characterized by the striking-even increasing-predominance of the USD as the currency of denomination. We find substantial cross-country variations in the association between the DEER and TREER indices, which turn out to have significant implications. Our growth regression estimates suggest that for countries with substantial debt-trade currency-compositional discord, marginal increases in nominal exchange rate variability exert significantly negative effects on growth. However, the sign of the effect is reversed as the extent of the debt-trade mismatch declines to remain lower than a certain threshold. In other words, nominal exchange rate variability can exert either a negative or positive effect on a country's economic growth, depending on the degree of harmony of the currency compositions between debt and trade. Given these novel findings, this study contributes to the literature on currency exposure from a unique angle.

The remainder of this study is organized as follows. Section 2 describes the data and examines the trends in the currency composition of external debt of MICs and LICs. Section 3 constructs the DEER indices to quantify the extent of their co-movements with the TREER series as our measures of mismatches. Section 4 examines the implications of the debt-trade mismatch by estimating growth regressions. Finally, section 5 provides concluding remarks.

\section{Currency composition of external debt}

\section{2.a Data and preliminaries}

We adopt the World Bank’s International Debt Statistics (IDS) as our primary data source. Supplementary data are extracted from the Bank’s World Development Indicator 
Database, and the International Monetary Fund's International Financial Statistics and Direction of Trade Statistics. The baseline sample period is 1980-2012, with occasional curtailment for countries with limited data availability.

The IDS provides information on the currency denomination of external debt but not assets. Therefore, we do not observe currency mismatches in the usual sense. ${ }^{6}$ Instead, we focus on the currency compositional discord between external debt and trade and its implications under nominal exchange rate fluctuations.

In the IDS database, the currency composition of external debt is available only for PPG debt. Although this availability may seem to severely limit the scope of our analyses, the share of PPG debt in total debt turns out to be quite high for both MICs and LICs. As Panel A of Table 1 indicates, more than an average of seventy percent of all debt stock of MICs is PPG debt. For LICs, the share of PPG debt is even higher, at approximately eighty-four percent. Replacing the debt stock with debt service will not significantly alter the picture. The average PPG share remains at seventy percent for MICs and increases to ninety-six percent for LICs. Therefore, PPG debt serves as a reasonable proxy for the total external debt of those countries. ${ }^{7}$

Panel B of Table 1 summarizes the currency composition of PPG debt stock. The average shares are noted for the USD, euro, Japanese yen (JPY), British pound (GBP), and Swiss franc (CHF). The sample period is 1980-2012, except for the euro, to which

${ }^{6}$ For the definition of currency mismatch, see Eichengreen, Hausmann, and Panizza (2007) among others. Given data constraints, we consider the currency denomination of external debt without netting out the value of foreign assets. Thus, our investigations are more closely related to original sin than currency mismatch.

${ }^{7}$ PPG debt is a reasonable, although imperfect, measure for the purpose of this paper for the following reason. The distinction between public and private sectors in less developed economies tends to be obscure in that their export and import sectors are often run by public or quasi-public agents, such as state enterprises (Claessens, 1992). Correspondingly, PPG debt includes not only sovereign debt but also debt by government-backed (quasi-)private enterprises. 
2001-2012 applies for obvious reasons. The shares of the deutsche mark (DM) and the French franc (FF) are also provided for the period of 1980-2000.

For both MICs and LICs, the USD is by far the most dominant currency with an average share of approximately fifty percent. The euro, the next on the list, is only approximately sixteen percent and eight percent for MICs and LICs, respectively. Thus, the dominance of the USD is outstanding. When combined, the aforementioned major currencies take up more than eighty percent and close to seventy percent of the external debt of MICs and LICs, respectively. These numbers unambiguously manifest the prevalence of original sin across MICs and LICs.

Because the currency compositional shares can shift over time, we provide time series plots of the country average shares in Figure 1. For both MICs and LICs, the graphs indicate that the USD is not just dominant but also exhibits a long-term increasing trend. The 2012 figures show that the shares of the USD well exceeded fifty percent and approached sixty percent.

\section{2.b Trends in currency composition}

Over time, do the borrowing countries show a significant diversification or concentration trend in the currency in which their debt is denominated? ${ }^{8}$ Are certain currencies gaining or losing importance in the debt denomination, and for whom? To answer these questions, we fit a linear trend to the time series of the compositional shares of the major currencies using

$$
\frac{P P G_{j, t}}{P P G_{t}}=\alpha_{j}+\beta_{j} t+\varepsilon_{j, t}
$$

\footnotetext{
${ }^{8}$ It is noted that the currency compositions can shift not only for new issues but also the existing debt stock via currency conversion options in rescheduling negotiations.
} 
For a given country, $P P G_{j, t}$ is the currency $j$-denominated PPG external debt in year $t$. $P P G_{t}$ is the total PPG debt of the country in the same year.

Panel C of Table 1 presents the numbers of countries for which the denoted currencies exhibit a significant upward or downward trend (noted with + and -, respectively) in their shares. The USD is evidently becoming even more dominant over time for both MICs and LICs because the number of countries with a significant upward trend far exceeds that with a downward trend. Specifically, the balance is forty-nine positives versus seventeen negatives for MICs, and twenty-one versus two for LICs. In contrast, more countries reduced their share of the euro than the number that increased such share, presumably attributed to recent debt crises. For the JPY, more MICs with an increasing trend exist than do those with a decreasing one. In contrast, the number of LICs with a downward JPY trend exceeds that with an upward trend.

Table 1 shows that the GBP and the CHF have been losing their ground as external debt denomination currencies. For both currencies, the number of MICs exhibiting a downward trend far exceeds that with an upward trend. Additionally, although no LICs show an upward trend in their shares, twenty-five and sixteen LICs have a significant downward trend in the shares of the GBP and the CHF, respectively.

Finally, the entries for currencies other than the major ones provide little signs of dissolving original sin. Overall, the external debt of MICs and LICs continues to be characterized by striking dominance of the USD and, to a lesser degree, a few other major currencies. Furthermore, in general, the dominance of the USD is increasing over time.

\section{2.c Regional stratification}


Conceivably, the geographical distributions of debtor countries and the countries of popular denominating currencies generate region-dependent non-homogeneous trends in currency composition. To examine this possibility, Tables 2.A and 2.B provide information on external debt by regionally-stratified sub-samples. ${ }^{9}$ In general, the major denominating currencies indicate a strong presence in the regions of geographical proximity and strong historical ties. For instance, the USD has the highest share, at sixty-seven percent, in Latin America and the Caribbean. Furthermore, twenty-one out of twenty-four countries in the region indicated an increasing trend in their USD share. Similarly, the share of the JPY is higher in East Asia and the Pacific than in other regions. The euro shows an eminent presence in Europe and Central Asia, and the Middle East and North Africa, although it also has a surprisingly high share in South Asia.

However, despite the aforementioned regional specificity, we observe the universal dominance of the USD. Even in East Asia and the Pacific, the share of the USD is more than twice that of the JPY. By the same token, the share of the USD dominates the euro in Europe and Central Asia, and the Middle East and North Africa. These observations stress that excessive reliance on USD-denominated debt is a global phenomenon, rather than a regional one.

As an alternative to summarizing the data, Figure 2 plots for each region the average share by currency as a time series. With possible exceptions of the Middle East and North Africa (Figure 2.E), where the euro almost caught up to the USD before the crisis, the predominance of the USD seems unshakable. In contrast, the trends in the average shares of the euro differ widely by region. Aside from the Middle East and North Africa,

\footnotetext{
9 The regional categories are as defined by the World Bank.
} 
the currency has steadily increased its share since its birth in Europe and Central Asia, and South Asia (Figures 2.B and 2.C). In South Asia, the increase in the euro's share is observed to be concurrent with a decline in the shares of the USD and the JPY.

Taken together, our findings on the currency compositions of PPG debt thus far make an interesting contrast to, for instance, those on private bond issuances as reported by Hale, Jones, and Spiegel (2014). These authors find a substantial decline in the share of international bonds denominated in the major currencies and an increase in bonds denominated in an issuer's home currencies during the last two decades. Nonetheless, aside from the difference in public versus private issuances, we note two additional sources of differences in the findings. Their country sample consisted primarily of advanced economies, including those of the major currencies. Additionally, they considered the new issuances, whereas we consider the stock.

\section{Fluctuations in exchange rates and debt burdens}

\section{3.a Debt-weighted effective exchange rates}

Depreciation of a domestic currency can have various consequences depending on the currencies against which it depreciates. A major concern for many MICs and LICs is the extent to which the depreciation increases the burden of their external debt. To capture the extent of the debt revaluation effect, constructing an index that measures the overall value of a debtor's currency against the currencies in which its external debt is denominated would be useful.

Using data on the currency composition of PPG debt and bilateral nominal exchange rates, we construct the DEER index 


$$
\operatorname{DEER}_{i, t}=\prod_{j}\left(\frac{S_{i, j, t}}{S_{i, j, 2010}}\right)^{\gamma_{i, j, t}}
$$

for which $\gamma_{i, j, t}$ is the share of currency $j$ for country i's external PPG debt in year $t$, and $S_{i, j, t}$ is the bilateral nominal exchange rate between $i$ 's currency and currency $j \in$ \{USD, euro, JPY, GBP, CHF, others\}. To make the index consistent with the real effective exchange rate series in the next sub-section, we use the bilateral nominal exchange rate measured by the number of currency $j$ per $i$ 's currency (i.e., the number of foreign currencies per domestic currency), and it is indexed to its 2010 value. $^{10}$

One data issue to note is how to treat debt denominated in currencies other than the major currencies. More specifically, the IDS database contains composition categories labeled "All other currencies" and "Multiple currencies" without further specifications on which currencies they actually are. Constrained by data limitations, we make a simplifying assumption that the debt in categories other than the major currencies is denominated in a debtor's own currency. This assumption makes the constructed DEER index appear more stable than it actually is. We keep this phenomenon in mind when interpreting the empirical results. Nonetheless, given the dominance of the major currencies in debt denomination as documented in the previous section, we believe that fluctuations against the major currencies draw the essential picture.

\section{3.b Debt revaluation and cost competitiveness gain in trade}

It is not only the value of foreign-currency-denominated debt that is affected when a debtor's exchange rate fluctuates. If a domestic currency depreciates against the currencies of a debtor's trading partners, then this depreciation can also translate into

${ }^{10}$ An increase in the debt-weighted effective exchange rate index indicates domestic appreciation. 
cost competitiveness gains in international trade. ${ }^{11}$ Consequently, this phenomenon should assist the indebted country to invigorate its economy and repay part of its external debt. The extent of the cost competitiveness gain effect depends on the currency compositions of debt and trade, which can vary substantially by country. Therefore, implications of domestic depreciation should also be diverse across countries accumulating external debt. The point is not sufficiently addressed in the previous literature on currency mismatch and original sin.

In this sub-section, we examine the association between the aforementioned two effects arising from exchange rate changes: the debt revaluation effect and the cost competitiveness gain effect. We do so by estimating the correlations between the DEER and TREER series. The novelty of this measure is that it succinctly reflects how the two distinct effects of exchange rate fluctuations interplay for a borrowing country. ${ }^{12}$ The feature is absent from the extant indices of currency mismatch that rely on the total value of external liabilities in relation to that of export and other assets at a given point in time. ${ }^{13}$

Unfortunately, the real effective exchange rate series are available only for a subset of the sample countries. Consequently, we have both the DEER and TREER indices for only fifty countries-the MICs and the LICs combined. As a supplementary indicator we consider the ratio of total debt stock (DSTC) to exports of goods, services, and primary income. In addition, we estimate the correlations between the DEERs and the

11 The relative inflation is assumed to be stable and does not offset exchange rate movements, at least in the short run.

12 The actual trade of a debtor country can be shaped in part by factors outside its own trade network. In this sense, the measure we propose does not exclude the third country effects since the TREER is based on the actual trade. The point should be borne in mind when interpreting the empirical results.

13 For instance, see Eichengreen, Hausmann, and Panizza (2007), Goldstein and Turner (2004), and Ranciere, Tornell, and Vamvakidis (2010b). 
bilateral nominal USD exchange rates (USDX) to use as a reference. To avoid spurious correlations, we use the first differences of logged data for all series.

Table 3 summarizes the correlations between the DEER and other series. Panel A presents the descriptive statistics when using all available observations. As a benchmark reference, we first report the correlation between the DEER and the USDX. The DEERUSDX correlation is notably high at 0.84 on average, confirming the dominance of the USD as a debt-denominating currency. Almost all countries in the sample exhibit a positive DEER-USDX correlation. ${ }^{14}$

The average correlation between the DEER and the TREER is 0.55. The positive correlation implies that exchange rate changes that increase the domestic currency value of external debt also tend to improve cost competitiveness in trade, albeit not in a one-for-one fashion. Nonetheless, the DEER-TREER correlation appears substantially lower than the DEER-USDX correlation. ${ }^{15}$ This finding implies that the heavy concentration on the USD in debt denomination drives a wedge between the extents of debt revaluation and trade competitiveness gains as the debtor's exchange rate fluctuates. Further, we notice that the DEER-TREER correlation is more variable than the DEER-USDX one. The minimum $(-0.50)$ and the maximum $(0.89)$ are recorded by Ukraine and Nigeria, respectively.

The positive DEER-TREER correlations suggest that domestic depreciation increases the burden of external debt on the one hand and improves the cost competitiveness in international trade on the other hand. What is the balance between

\footnotetext{
14 The only country that exhibits a negative correlation is Azerbaijan. At the other extreme, Kosovo shows a correlation of unity implying that all of their PPG debt is denominated in USD.

${ }^{15}$ The result is not an artifact of different sample sizes. As shown in Panel B of Table 3, using the identical samples does not alter the conclusion.
} 
the two effects? The bottom row of the panel reports the DEER correlations with debt stock as a percentage of the export of goods, services, and primary income. A decline in the value of the DEER indicates domestic depreciation. Although the ratio between the debt stock and exports can translate into both revaluation of external debt and growth in exports, it can increase or decrease to generate a negative or positive DEER-DSTC correlation. $^{16}$

As displayed in the bottom row of Panel A, the DEER-DSTC correlation varies substantially by country and ranges from -0.68 (Ethiopia) to 0.92 (Myanmar), with a mean near zero. The distributional balance between positive and negative correlations also reveals the non-unanimity of the countries. Specifically, sixty-eight and fifty countries exhibit positive and negative correlations, respectively. Again, the main message is that countries are diverse in their experiences of debt revaluation and cost competitiveness gain effects under exchange rates fluctuations.

Although we have used all available observations so far, the differences in the samples make it difficult to compare the entries across rows in Panel A of Table 3. Thus, we recalculate the statistics using a common sample consisting only of countries and years for which all necessary data are available. This recalculation reduces the sample size to forty-five. The common sample results are summarized in panel B. They turn out quite comparable to those in panel $\mathrm{A}$, requiring no significant alteration to our conclusions.

Figure 3 presents the DEER-TREER correlation estimates by subsamples to visualize possible heterogeneity. As displayed, LICs tends to have a higher correlation and, hence, more accordant currency compositions than MICs. When classified by ${ }^{16}$ Note that the ratio of debt to exports and not net exports is observable from the available data. 
region, Europe and Central Asia, and sub-Saharan Africa, respectively, have the lowest and highest correlations. Their difference is statistically significant. ${ }^{17}$

\section{Implications of the debt-trade "mismatch"}

\section{4.a Augmented growth regression specifications}

In view of the aforementioned results, we are now poised to raise an essential question: Does the extent of the currency-compositional discord between external debt and international trade have significant welfare implications as hypothesized in the introduction section? We answer the question by estimating growth regressions to test whether the extent of the debt-trade mismatch exerts a significant effect on a country's growth performance.

Specifically, we estimate the following cross-country regression equation

$$
\Delta Y_{i}=\alpha+\gamma^{\prime} X_{i}+\phi_{1} V O L_{i}+\phi_{2} C O R_{i}+\phi_{3}\left(V O L_{i} \times C O R_{i}\right)+\varepsilon_{i},
$$

for which $\Delta Y_{i}$ is the average growth rate of per capita real GDP of country i. $X_{i}$ is a vector of standard growth regression variables included as controls. They are the initial level of GDP per capita (in logarithm), investment, government consumption, population growth rate, secondary education school enrollment rate, trade openness (i.e., total trade to GDP), and debt stock. ${ }^{18}$ Investment, government consumption, and debt stock are measured in relative terms to GDP. With the exception of the initial level of GDP per capita, the control variables are measured in their sample average terms.

\footnotetext{
17 The subsample averages are tested for equality. We additionally investigated whether the DEER-TREER correlations differ by exchange rate regimes using the three-way classification scheme of Levi-Yeyati and Sturzenegger (2005). The cross-regime differences in average correlations are found to be statistically insignificant.

${ }^{18}$ Investment is measured using gross fixed capital formation. For the choice of controls, see Barro (1991), Durlauf and Quah (1999), Levy Yeyati and Panizza (2011), and Panizza and Presbitero (2014), among many others.
} 
The regressors of our primary interest are those with $\phi$ coefficients. Namely, $V O L_{i}$ is the exchange rate volatility measured using variances of the first differences of logged nominal effective exchange rates. $C O R_{i}$ is the DEER-TREER correlation. A larger $C O R_{i}$ value indicates closer co-movement driven by more accordant currency compositions and, hence, a smaller extent of the debt-trade mismatch.

We emphasize that the interaction term, $V O L_{i} \times C O R_{i}$, in (3) is indispensable because the growth effect of the debt-trade mismatch should depend on how much $i$ 's nominal exchange rate actually changes. For instance, when a country's exchange rate stays perfectly still, no revaluation effect on its external debt exists. ${ }^{19}$ Only to the extent that a country's nominal exchange rate actually fluctuates, its external debt valuation also changes. Then, considering how much of the debt revaluation effect will be compensated by the cost competitiveness gain effect that also arises from the exchange rate fluctuations becomes meaningful. Omitting the interaction term from (3) results in a specification that restricts the extent of the debt-trade mismatch to affect all countries in an identical manner regardless of the extent of exchange rate variability, and vice versa.

Note that in (3), the effect of the DEER-TREER correlations on growth is measured by $\phi_{2}+\phi_{3} V O L_{i}$. We stress that $\phi_{2}$ does not represent the marginal effect of the DEERTREER correlations on growth. Instead, it measures the effect of the DEER-TREER correlations when no nominal exchange rate variability exists. Because nominal effective exchange rates fluctuate even for countries with a successful fixed exchange rate regime, $V O L_{i}$ takes a positive value for all countries.

\section{4.b Empirical results}

${ }^{19}$ Consequently, currency mismatch is not even an issue. 
Table 4 summarizes the estimates of (3) and its variants. We begin with a bare-boned specification that includes only the conventional growth regression variables. The estimates are provided in Column 1 of Table 4. The signs of the coefficient estimates are in accordance with the expectations based on the literature. The effect of the initial income level is significantly negative, implying convergence. The investment ratio exerts a highly significant positive effect, whereas government consumption has a negative effect with only moderate significance. Although statistically insignificant, the population growth and school enrollment rates obtain negative and positive coefficients, respectively, which is in line with the conventional theoretical predictions and the existing evidence. The effect of the trade openness variable also turns out to be insignificant. The debt to GDP ratio has a significantly negative effect on growth, which is consistent with the findings of recent studies (Reinhart and Rogoff, 2010 and 2011). ${ }^{20}$

In columns 2 and 3, we report the estimates when incrementally including $V O L_{i}$ and $C O R_{i}$ without allowing their interaction. These constrained estimates suggest that exchange rate volatility by itself does not exert a significant effect on growth. A similar observation is made on the effect of $C O R_{i}$. The adjusted r-squared estimates indicate deterioration of the model's explanatory power relative to the bare-boned specification.

In contrast, the unconstrained specification estimates of (3) reported in column 4 reveal significant effects. The exchange rate volatility variable obtains a significant negative coefficient, whereas the interaction term $V O L_{i} \times C O R_{i}$ attains a significant positive effect. Further, the adjusted r-squared estimates attest noticeable improvement in terms of explanatory power.

${ }^{20}$ Panizza and Presbitero (2014) noted that for a sample of OECD countries, negative debt-growth correlation may be driven by a third factor and is not the product of a direct causal effect. See also Kourtellos, Stengos, and Tan (2013) for related evidence. 
As already noted, the coefficient estimate on $V O L_{i}$ (i.e., $\hat{\phi}_{1}$ ) does not represent the marginal effect of exchange rate volatility on economic growth. Instead, it gauges the exchange rate volatility effect when $C O R_{i}$ is zero. Because $\hat{\phi}_{3}$, the coefficient on the interaction term, is significantly positive, as the value of $C O R_{i}$ increases (i.e., as the extent of debt-trade mismatch diminishes), the negative effect of exchange rate volatility is reduced. In fact, the combined effect, $\hat{\phi}_{1}+\hat{\phi}_{3} C O R_{i}$, turns positive once $C O R_{i}$ exceeds a certain threshold. That is, nominal effective exchange rate volatility can exert either growth-hindering or growth-enhancing effects depending on the level of the debt-trade currency-compositional discord. ${ }^{21}$

For the combined effect of exchange rate volatility to be positive for growth, the DEER-TREER correlation must exceed 0.65 . This threshold value slightly exceeds the median value (0.63). More specifically, of the 45 countries in the sample, 21 possess DEER-TREER correlation values greater than $0.65 .^{22}$ For these countries, the DEERTREER correlation is substantial (i.e., the debt-trade currency-compositional mismatch is small) enough for marginal increases in exchange rate variability to have an overall stimulating effect on growth. In contrast, the majority of the countries experience downward pressure on growth when their exchange rates become more volatile.

21 In considering the effects of capital account liberalization, Henry (2007) argues that purely cross-sectional growth regressions are problematic since they cannot identify temporary shifts in growth rates. In our regressions, exchange rate fluctuations can occur repeatedly unlike the one-shot permanent liberalization of capital account in Henry (2007). Thus, even though each shock may have only temporary effects, recurrent shocks can lead to differences in average growth rates.

22 Specifically, the 21 countries are Cameroon, Colombia, Costa Rica, Cote d'Ivoire, Dominica, Gabon, Georgia, Grenada, Macedonia, Malaysia, Moldova, Nicaragua, Nigeria, Philippines, Romania, South Africa and Venezuela (17 MICs); and Central Africa Republic, Gambia, Malawi, and Togo (four LICs). 
To check the robustness of the results, we additionally estimate a specification that controls for the amount of foreign exchange reserves relative to GDP. As discussed in the introduction, reserves can play an important role as buffer assets and, thus, may affect growth performance. However, the estimates reported in column 5 indicate no significant changes to our findings. The reserve variable is insignificant, whereas the effects on the key regressors remain virtually intact, suggesting robustness of our chief results.

\section{Conclusions}

For emerging and less developed economies, borrowing abroad typically means borrowing in foreign currencies. Heavy reliance on foreign currency-denominated debt

makes the borrowing countries more vulnerable to the debt revaluation effect of domestic depreciation. Although the predominance of USD as a debt denomination currency has been recognized as a significant factor behind recurrent crises, the empirical evidence in this study shows no indication that this predominance is subsiding. In fact, we find that the USD is becoming more dominant than ever as the choice of a denominating currency for external debt among many MICs and LICs.

Even though many countries need to borrow abroad in foreign currencies, more than just one foreign currency exists to denominate the debt. When the currency compositions of external debt and international trade are in adequate accordance, domestic depreciation that increases the burden of external debt also leads to cost competitiveness gains for international trade. Thus, the debt revaluation effect is more likely to be offset, at least partially, by a subsequent increase in net exports. In a sense, 
a self-alleviation mechanism can be built by having the "right" currency compositions to denominate a country’s external debt.

The correspondence between the currency compositions of external debt and international trade can have important implications for the economic performance of debtor countries. Indeed, our growth regression results attest that countries with more accordant debt-trade currency compositions tend to have growth advantages. In other words, from the countries with original sin and currency mismatches, certain ones suffer from "another mismatch" and others do not. The issue is not whether to borrow in foreign currencies; instead, the issue is who borrows in which foreign currencies and trades with whom. Thus, the implications of seemingly excessive USD-debt, for instance, are not the same across countries. In summary, not all original sin is equally sinful.

Needless to say, borrowers cannot unilaterally and freely select the currencies in which their debt will be denominated. Nonetheless, lenders should also be interested in avoiding debt crises and detrimental economic consequences. In this sense, the findings of this study suggest that it is worth reconsidering the currency denomination strategies of the external debt of MICs and LICs. In doing so, it is also important to understand the strategic currency choice by exporting firms examined in the other chapter.

Countries with significant debt-trade currency compositional mismatches bear implicit costs in terms of growth that might be avoided by revising the currency compositions of their external debt denomination. The cost is implicit in that the significant growth-suppressing effect of another mismatch has not been explicitly recognized in the previous literature. 
Of course, altering the currency composition of external debt is not costless. For instance, Caballero and Krishnamurthy (2003) found that financial underdevelopment in emerging markets makes agents undervalue insuring against domestic depreciation. A crucial consequence is that they choose, rather than being forced, to use excessive dollar debt. If so, domestic financial development needs to precede rebalancing of the currency compositions of the external debt. In general, the extent of financial development can be a factor influencing the relationship between the choice of currency compositions of debt and economic performance.

In addition, the real cost of the debt-trade currency compositional mismatch needs to be evaluated by netting out its benefit. With the USD as the debt denomination currency, borrowers are likely to have better access to external capital. Thus, the balance between accessibility and risk needs to be considered.

Finally, although the analytical focus of this study is set specifically on the debttrade mismatch, examining whether the growth effects we find extend to a broader measure of currency exposure, such as that proposed by Lane and Shambaugh (2009), would be interesting. These issues are reserved for future research. 


\section{Data Appendix}

\section{Sources}

The data used in this study are obtained from the following sources:

International Debt Statistics, World Bank.

World Development Indicators, World Bank.

International Financial Statistics, International Monetary Fund.

Direction of Trade Statistics, International Monetary Fund.

\section{Sample period}

The primary sample period is 1980-2012. Depending on data availability, some countries have shorter samples.

Euro: exchange rate 1999-2012; currency composition 2001-2012.

Deutsche mark and French franc: exchange rate 1980-1998; currency composition 1980-2000. The exchange rates for 1999 and 2000 are set to 1 euro $=1.95583 \mathrm{DM}$ and 1 euro $=6.55957 \mathrm{FF}$.

\section{Sample countries}

Our sample consists of all middle- and low-income countries in the WDI for which data on external debt currency composition are available. The MIC and LIC samples, respectively, consist of ninety-one and thirty-three countries listed below. For the analyses in sections 3 and 4, the number of countries in the samples is further reduced because of limited data availability.

Middle-income countries (91 countries): Albania, Algeria, Angola, Argentina, Armenia, Azerbaijan, Belarus, Belize*, Bhutan, Bolivia*, Bosnia and Herzegovina, Botswana, Brazil, Bulgaria*, Cabo Verde, Cameroon*, China*, Colombia*, Republic of Congo, Costa Rica*, Cote d'Ivoire*, Djibouti, Dominica*, Dominican Republic*, Ecuador, Egypt, El Salvador, Fiji*, Gabon*, Georgia*, Ghana*, Grenada*, Guatemala, Guyana*, Honduras, Hungary*, India, Indonesia, Iran*, Jamaica, Jordan, Kazakhstan, Kosovo, Kyrgyz Republic, Lao PDR, Lebanon, Lesotho*, Macedonia*, Malaysia*, Maldives, Mauritania, Mauritius, Mexico*, Moldova*, Mongolia, Montenegro, Morocco*, Nicaragua*, Nigeria*, Pakistan*, Panama, Papua New Guinea*, Paraguay*, Peru, Philippines*, Romania*, Samoa, Sao Tome and Principe, Senegal, Serbia, Seychelles, Solomon Islands, South Africa*, Sri Lanka, St. Lucia*, St. Vincent and the Grenadines*, Sudan, Swaziland, Syrian Arab Republic, Thailand, Tonga, Tunisia*, 
Turkey, Turkmenistan, Ukraine*, Uzbekistan, Vanuatu, Venezuela*, Vietnam, Yemen, Zambia.

Low-income countries (33 countries): Afghanistan, Bangladesh, Benin, Burkina Faso, Burundi*, Cambodia, Central African Republic*, Chad, Comoros, Democratic Republic of Congo*, Eritrea, Ethiopia, Gambia*, Guinea, Guinea-Bissau, Haiti, Kenya, Liberia, Madagascar, Malawi*, Mali, Mozambique, Myanmar, Nepal, Niger, Rwanda, Sierra Leone*, Somalia, Tajikistan, Tanzania, Togo*, Uganda*, Zimbabwe.

“*” indicates countries for which data availability allows us to calculate the DEERTREER correlations. These 45 countries constitute the sample for the growth regressions in section 4 . 


\section{Reference:}

Barro, Robert J. 1991. Economic growth in a cross section of countries. Quarterly Journal of Economics, 106 (2), 407-443.

Borensztein, Eduardo and Ugo Panizza. 2010. Do sovereign defaults hurt exporters? Open Economies Review, 21, 393-412.

Caballero, Ricardo and Arvind Krishnamurthy. 2003. Excessive dollar debt: Financial development and underinsurance. Journal of Finance, 58 (2), 867-893.

Claessens, Stijn. 1992. The optimal currency composition of external debt: Theory and applications to Mexico and Brazil. World Bank Economic Review, 6 (3), 503-528.

Durlauf, Steven N. and Danny T. Quah. 1999. The new empirics of economic growth. In John B. Taylor and Michael Woodford (eds.), Handbook of Macroeconomics Vol. 1A, pp. 235-308. Amsterdam: Elsevier.

Eichengreen, Barry, Ricardo Hausmann, and Ugo Panizza. 2007. Currency mismatches, debt intolerance, and the original sin: why they are not the same and why it matters, in S. Edwards (ed.), Capital Controls and Capital Flows in Emerging Economies: Policies, Practices and Consequences, NBER, University of Chicago Press, Chicago.

Goldstein, Morris and Philip Turner. 2004. Controlling currency mismatches in emerging markets, Institute of International Economics, Washington DC.

Hale, Galina B., Peter Jones, and Mark M. Spiegel. 2014. The rise in home currency issuance. Federal Reserve Bank of San Francisco Working Paper Series 2014-19.

Hausmann, Ricardo and Ugo Panizza. 2003. On the determinants of original sin: An empirical investigation. Journal of International Money and Finance 22, 957-990.

Henry, Peter B. 2007. Capital Account Liberalization: Theory, Evidence, and Speculation. Journal of Economic Literature, 45(4), 887-935. 
Kourtellos, Andros, Thanasis Stengos, and Chih Ming Tan. 2013. The effect of public debt on growth in multiple regimes. Journal of Macroeconomics, 38, 35-43.

Lane, Philip R. and Jay C. Shambaugh. 2009. Financial exchange rates and international currency exposures. American Economic Review, 99 (1), 1-30.

Levi-Yeyati, Eduardo and Ugo Panizza. 2011. The elusive costs of sovereign defaults. Journal of Development Economics, 94, 95-105.

Levy-Yeyati, Eduardo and Federico Sturzenegger. 2005, "Classifying exchange rate regimes: Deeds vs. words,” European Economic Review, 49 (6), 1603-1635.

Mankiw, N. Gregory, David Romer, and David N. Weil. 1992. A contribution to the empirics of economic growth. Quarterly Journal of Economics, 107(2), 407-437.

Panizza, Ugo and Andrea F. Presbitero. 2014. Public debt and economic growth: Is there a causal effect? Journal of Macroeconomics, 41, 21-41.

Ranciere, Romain, Aaron Tornell, and Athanasios Vamvakidis. 2010a. Currency Mismatch, Systemic Risk and Growth in Emerging Europe. Ec onomic Policy, 597-658.

Ranciere, Romain, Aaron Tornell, and Athanasios Vamvakidis. 2010b. A New Index of Currency Mismatch and Systemic Risk. IMF Working Paper WP/10/263.

Reinhart, Carmen M. and Kenneth S. Rogoff. 2010. Growth in a time of debt. American Economic Review: Papers and Proceedings, 100, 573-578.

Reinhart, Carmen M. and Kenneth S. Rogoff. 2011. From financial crash to debt crisis. American Economic Review, 101, 1676-1706.

Sokolova, Maria V. 2015. Strategic currency choice in international trade. The Graduate Institute of International and Development Studies, Geneva, Switzerland. 
Table 1. Currency composition of PPG external debt

\begin{tabular}{lll}
\hline & Middle-income countries & Low-income countries \\
\hline Number of countries & 91 & 33
\end{tabular}

A. Share of PPG debt (\%)

$\begin{array}{lll}\text { Debt stock } & 70.22 & 83.62 \\ \text { Debt service } & 70.24 & 95.93\end{array}$

B. Currency composition (\%)

US dollar

Euro

Deutsche mark

French franc

Japanese yen

British pound

Swiss franc

Major currencies

Others
50.14

16.15

3.49

5.26

6.76

2.07

0.95

81.35

9.78
49.05

8.22

1.64

5.52

4.49

1.94

0.93

68.17

17.21

C. Trends by currency

US dollar

Euro

Japanese yen

British pound

Swiss franc

Others
$+49,-17$

$+22,-33$

$+36,-20$

$+2,-56$

$+5,-45$

$+31,-43$
$+21,-2$

$+4,-12$

$+6,-8$

$+0,-25$

$+0,-16$

$+12,-13$

Notes: In panel A, the average shares of public and publicly guaranteed debt stock (service) in total debt stock (service) are reported. The sample period is 1980-2012. In panel B, "Major currencies" refers to the total shares of the U.S. dollar, euro, Japanese yen, British pound, and Swiss franc. For 1980-2000, the euro is replaced by the German mark and the French franc. "Others" indicates the shares of all currencies other than those in "Major currencies." The sample period is 1980-2012 except for the euro (2001-2012), deutsche mark (1980-2000), and French franc (1980-2000). In panel C, entries with a “+ (-)" sign denote the numbers of countries exhibiting a positive (negative) trend in the share of the corresponding currency in the first column. Trends are estimated by (1) in the main text. 
Table 2.A Currency composition of PPG external debt by region

\begin{tabular}{llll}
\hline & $\begin{array}{l}\text { East Asia \& the } \\
\text { Pacific }\end{array}$ & $\begin{array}{l}\text { Europe \& } \\
\text { Central Asia }\end{array}$ & South Asia \\
\hline Number of countries & 16 & 21 & 8
\end{tabular}

A. Share of PPG debt (\%)

$\begin{array}{llll}\text { Debt stock } & 72.90 & 55.57 & 85.10 \\ \text { Debt service } & 69.15 & 52.91 & 78.71\end{array}$

B. Currency composition (\%)

$\begin{array}{lrrr}\text { US Dollar } & 40.71 & 54.99 & 47.12 \\ \text { Euro } & 5.17 & 25.43 & 6.55 \\ \quad \text { Deutsch mark } & 2.80 & 5.23 & 2.11 \\ \quad \text { French franc } & 2.99 & 0.82 & 0.96 \\ \text { Japanese yen } & 16.56 & 6.88 & 10.17 \\ \text { British pound } & 1.72 & 0.19 & 2.16 \\ \text { Swiss franc } & 0.46 & 1.60 & 0.15 \\ \text { Major currencies } & 74.77 & 91.02 & 67.54 \\ \text { Others } & 11.53 & 3.19 & 12.09\end{array}$

C. Trends by currency

$\begin{array}{llll}\text { US Dollar } & +10,-2 & +6,-6 & +3,-1 \\ \text { Euro } & +0,-6 & +10,-6 & +1,-3 \\ \text { Japanese yen } & +6,-4 & +9,-2 & +5,-1 \\ \text { British pound } & +0,-11 & +2,-6 & +0,-7 \\ \text { Swiss franc } & +1,-8 & +1,-8 & +0,-3 \\ \text { Others } & +5,-6 & +10,-9 & +1,-6\end{array}$

Notes: The entries are for the countries that belong to the regional categories denoted at the top. See also the notes for Table 1. 
Table 2.B Currency composition of PPG external debt by region

\begin{tabular}{llll}
\hline & $\begin{array}{l}\text { Latin America } \\
\text { \& the Caribbean }\end{array}$ & $\begin{array}{l}\text { Middle East \& } \\
\text { North Africa }\end{array}$ & $\begin{array}{l}\text { Sub-Saharan } \\
\text { Africa }\end{array}$ \\
\hline Number of countries & 24 & 10 & 45 \\
& & & \\
A. Share of PPG debt (\%) & & & \\
$\quad$ Debt stock & 73.06 & 77.23 & 80.21 \\
Debt service & 71.96 & 80.97 & 74.24 \\
& & & \\
B. Currency composition (\%) & & & \\
US Dollar & 67.18 & 43.52 & 43.35 \\
Euro & 5.70 & 28.80 & 14.38 \\
$\quad$ Deutsche mark & 1.95 & 3.76 & 2.58 \\
$\quad$ French franc & 2.03 & 10.77 & 9.40 \\
Japanese yen & 3.58 & 7.33 & 2.52 \\
British pound & 2.98 & 0.93 & 2.73 \\
Swiss franc & 0.23 & 0.66 & 1.42 \\
Major currencies & 89.28 & 79.49 & 68.15 \\
Others & 4.74 & 16.15 & 18.53 \\
& & & \\
C. Trends by currency & & & \\
US Dollar & $+21,-1$ & $+3,-7$ & $+27,-2$ \\
Euro & $+2,-12$ & $+5,-2$ & $+8,-16$ \\
Japanese yen & $+5,-9$ & $+6,-1$ & $+11,-11$ \\
British pound & $+0,-18$ & $+0,-5$ & $+0,-34$ \\
Swiss franc & $+0,-13$ & $+1,-6$ & $+2,-23$ \\
Others & $+2,-17$ & $+5,-3$ & $+20,-15$ \\
\hline
\end{tabular}

Notes: See the notes for Table 2.A. 
Table 3. Correlations between debt-weighted effective exchange rate and other indices

\begin{tabular}{cccccccc}
\hline & Sample size & Positive & Negative & Mean & Std. dev. & Minimum & Maximum \\
\hline A. Maximum sample & & & & & & & \\
(DEER, USDX) & 111 & 110 & 1 & 0.84 & 0.19 & -0.37 & 1.00 \\
(DEER, REER) & 50 & 48 & 2 & 0.55 & 0.30 & -0.50 & 0.89 \\
(DEER, DSTC) & 118 & 68 & 50 & 0.02 & 0.28 & -0.68 & 0.92 \\
B. Common sample & & & & & & & \\
(DEER, USDX) & 45 & 45 & 0 & 0.85 & 0.15 & 0.30 & 0.99 \\
(DEER, REER) & 45 & 43 & 2 & 0.53 & 0.31 & -0.50 & 0.89 \\
(DEER, DSTC) & 45 & 22 & 23 & -0.02 & 0.26 & -0.53 & 0.59 \\
\hline
\end{tabular}

Notes: The entries indicate correlations among the followings: debt-weighted effective exchange rates (DEER), trade-weighted real effective exchange rates (TREER), bilateral USD rates (USDX), and external debt stocks (DSTC) as percents of exports of goods, services, and primary income. The correlations are based on the first difference of the logged series. Panel A contains statistics based on all available observations. In panel B, the correlations are calculated using the identical country and year samples. 
Table 4. Growth regression estimates

\begin{tabular}{|c|c|c|c|c|c|}
\hline & 1 & 2 & 3 & 4 & 5 \\
\hline \multirow[t]{2}{*}{ Initial GDP } & $-.857^{*}$ & $-.906^{*}$ & $-.960 *$ & $-1.032 * *$ & $-.962 * *$ \\
\hline & $(.336)$ & (.348) & (.369) & $(.355)$ & $(.322)$ \\
\hline \multirow[t]{2}{*}{ Investment } & $.205^{* *}$ & $.201 * *$ & $.198 * *$ & $.179 * *$ & $.171^{* *}$ \\
\hline & $(.065)$ & $(.064)$ & $(.062)$ & $(.063)$ & $(.055)$ \\
\hline \multirow[t]{2}{*}{ Government cons. } & $-.114^{\dagger}$ & $-.117^{\dagger}$ & $-.109^{\dagger}$ & $-.123 *$ & $-.119 *$ \\
\hline & $(.064)$ & $(.065)$ & $(.063)$ & $(.056)$ & $(.055)$ \\
\hline \multirow[t]{2}{*}{ Population growth } & -.181 & -.190 & -.207 & -.086 & -.093 \\
\hline & (.313) & (.317) & (.325) & $(.343)$ & (.353) \\
\hline \multirow[t]{2}{*}{ School enrollment } & .016 & .015 & .019 & .024 & .023 \\
\hline & (.013) & (.013) & $(.014)$ & $(.015)$ & (.015) \\
\hline \multirow[t]{2}{*}{ Trade openness } & -.003 & -.001 & -.001 & -.001 & -.001 \\
\hline & $(.007)$ & $(.007)$ & $(.007)$ & $(.007)$ & $(.008)$ \\
\hline \multirow[t]{2}{*}{ Debt stock/GDP } & $-1.184 *$ & $-1.547^{*}$ & $-1.534 *$ & $-1.559 *$ & $-1.301^{*}$ \\
\hline & (.508) & (.621) & (.625) & $(.568)$ & $(.571)$ \\
\hline \multirow[t]{2}{*}{ VOL } & & .097 & .097 & $-1.852^{*}$ & $-1.854^{*}$ \\
\hline & & (.225) & $(.202)$ & (.695) & $(.712)$ \\
\hline \multirow[t]{2}{*}{ COR } & & & .677 & -.517 & -.564 \\
\hline & & & $(.877)$ & (1.035) & (1.055) \\
\hline \multirow[t]{2}{*}{$\mathrm{VOL} \times \mathrm{COR}$} & & & & $2.848 * *$ & $2.817^{* *}$ \\
\hline & & & & $(.985)$ & (1.004) \\
\hline \multirow[t]{2}{*}{ Reserves/GDP } & & & & & .003 \\
\hline & & & & & $(.006)$ \\
\hline Adjusted $\mathrm{R}^{2}$ & .527 & .520 & .521 & .562 & .557 \\
\hline $\mathrm{n}$ & 45 & 45 & 45 & 45 & 45 \\
\hline
\end{tabular}

Notes: The entries summarize the estimates of the cross-country growth regression (3) in the main text and some variant specifications. The sample size is 45 for all estimates. Heteroskedastic-robust standard errors are provided in parentheses. VOL is the variances of the nominal effective exchange rates. COR is the correlation between debt-weighted effective exchange rates and trade-weighted real effective exchange rates. First differences of the logged data are used for all exchange rates. 
Figure 1. Average PPG share by denominating currency (\%)

A. Middle-income countries

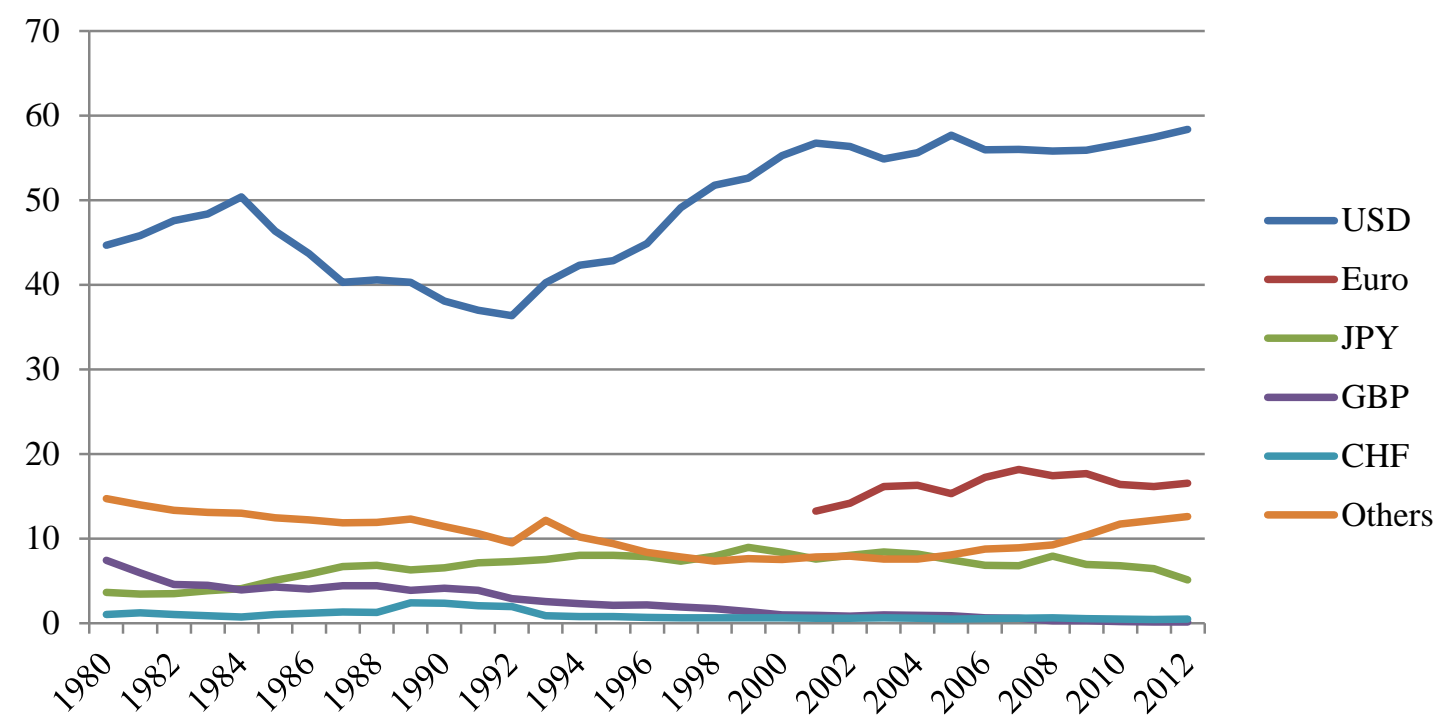

B. Low-income countries

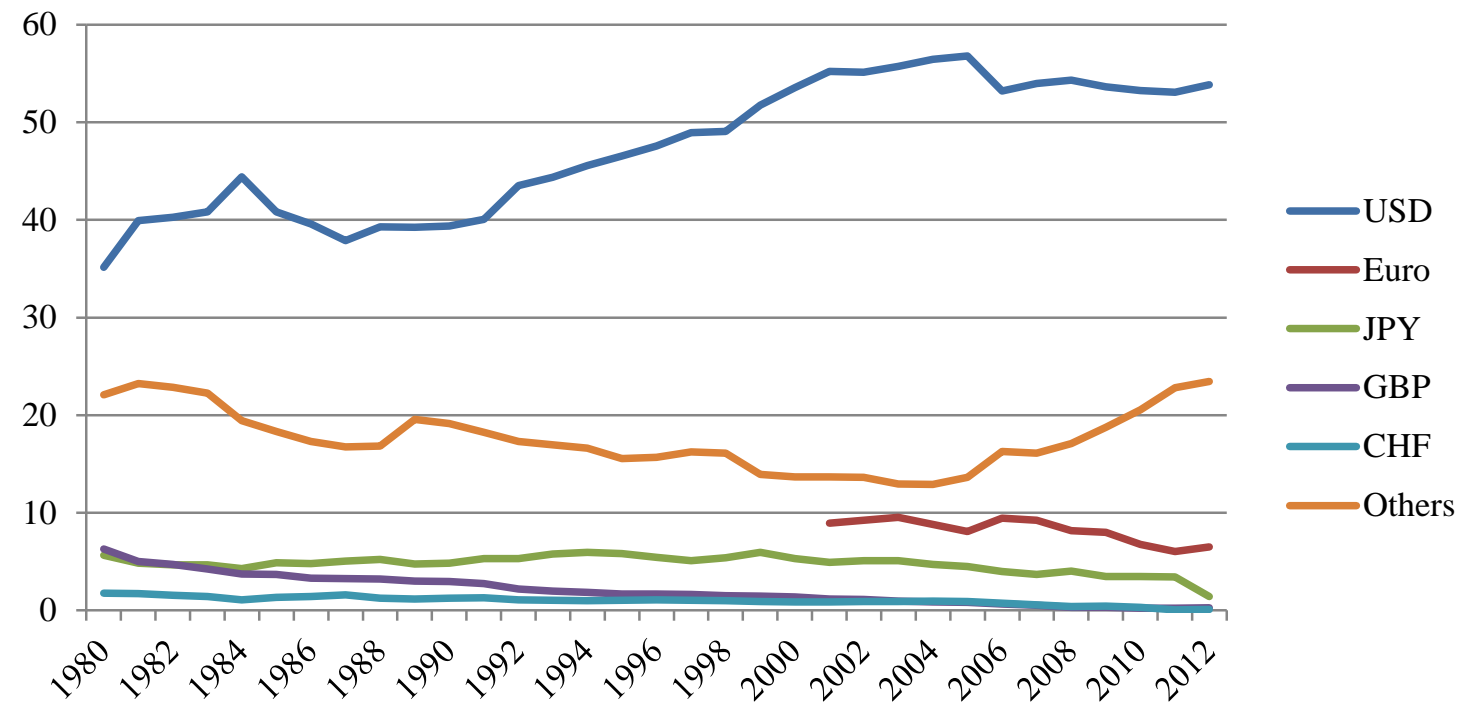

Notes: The figures depict the cross-country averages of the percentage shares of PPG debt by denominating currency. 
Figure 2. Regional average PPG share by denominating currency (\%)

A. East Asia and the Pacific

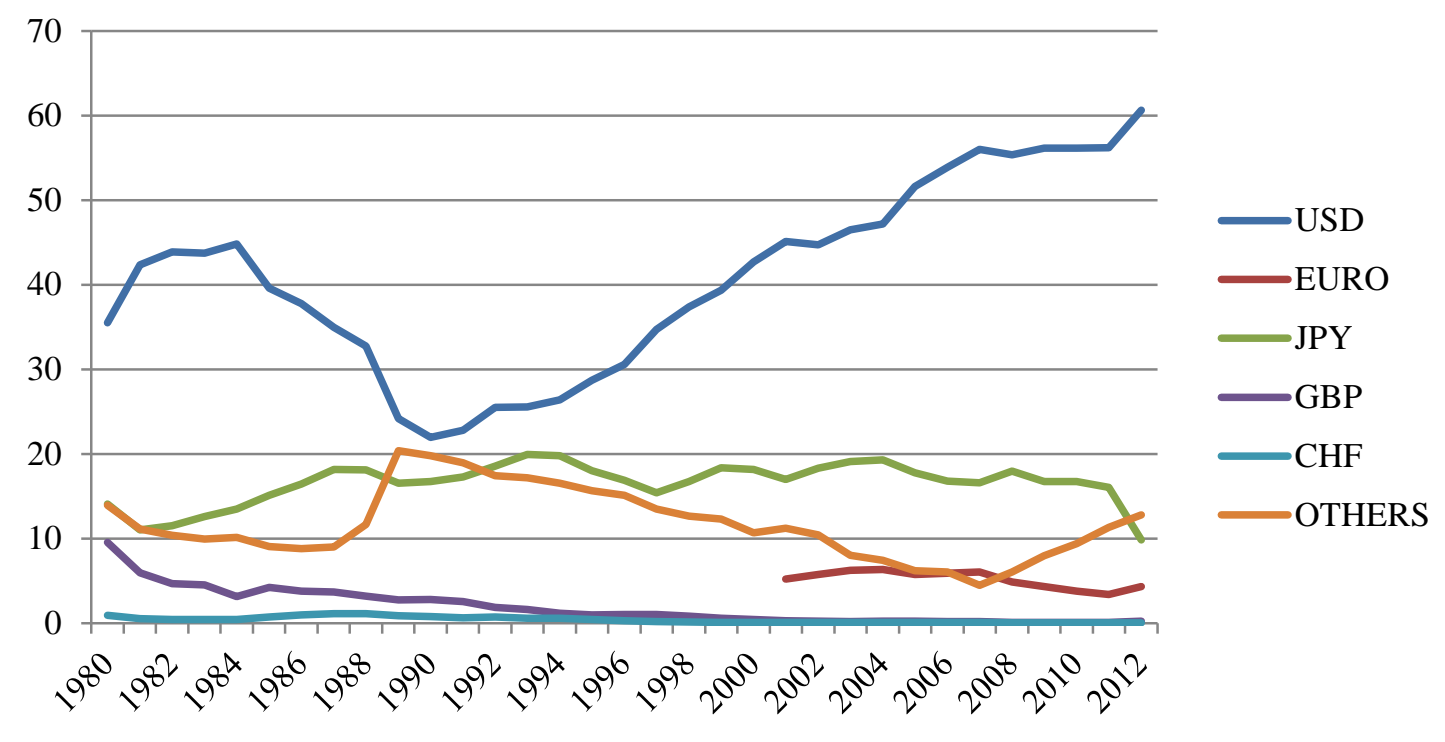

B. Europe and Central Asia

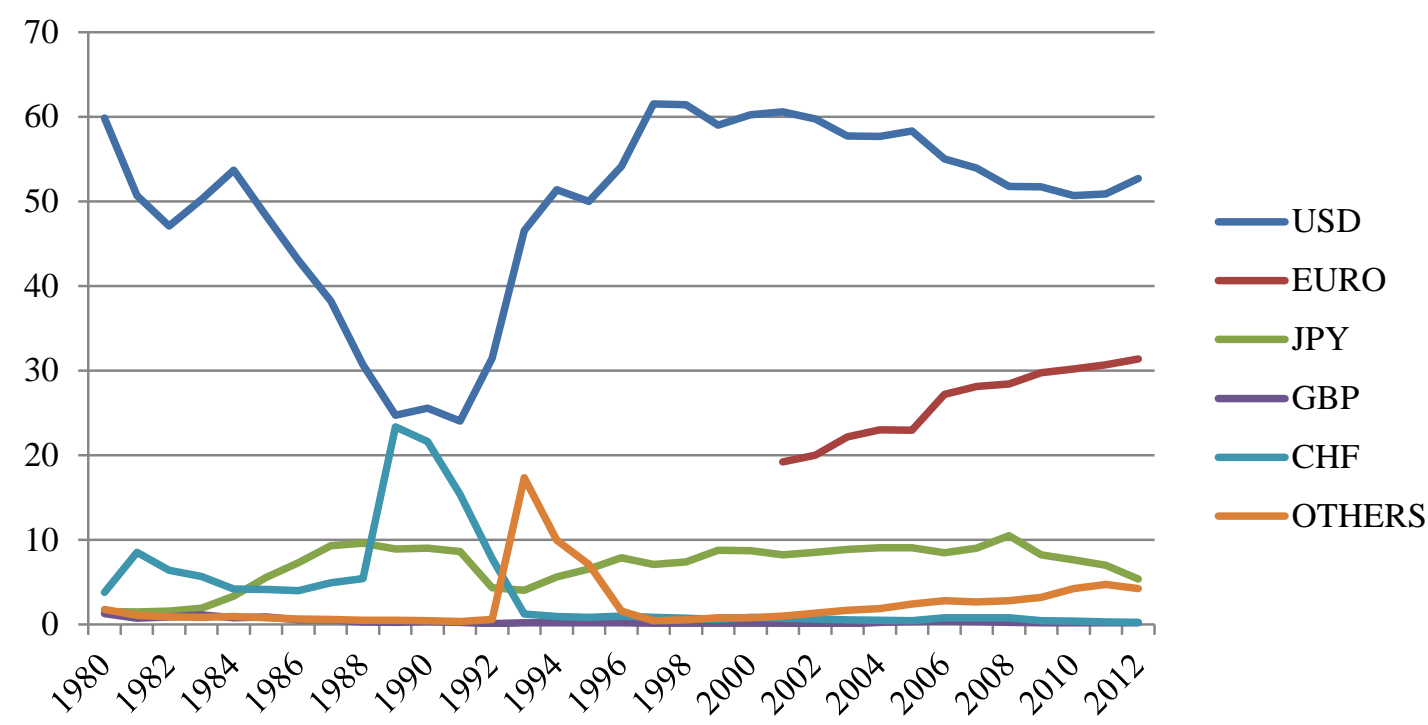


Figure 2. Regional average PPG share by denominating currency (\%) C. South Asia

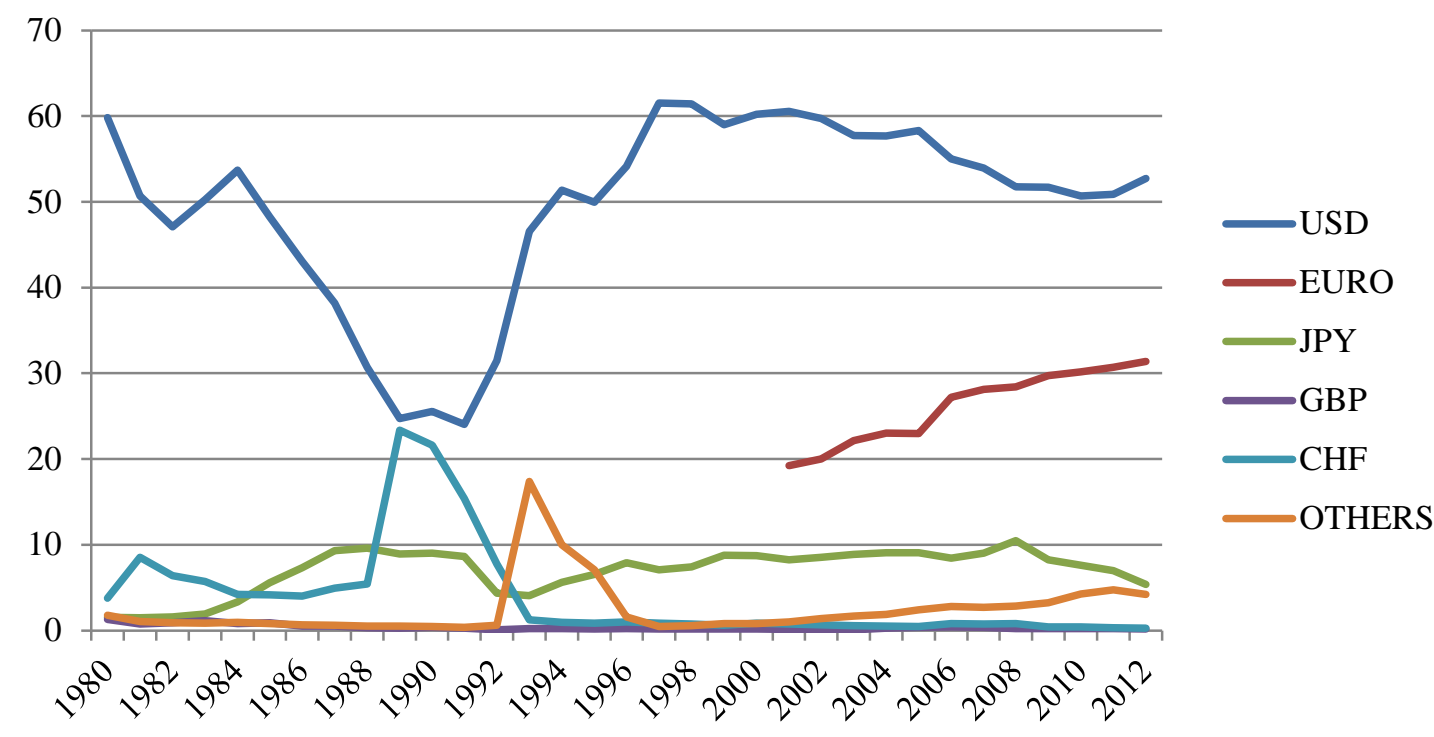

D. Latin America and the Caribbean

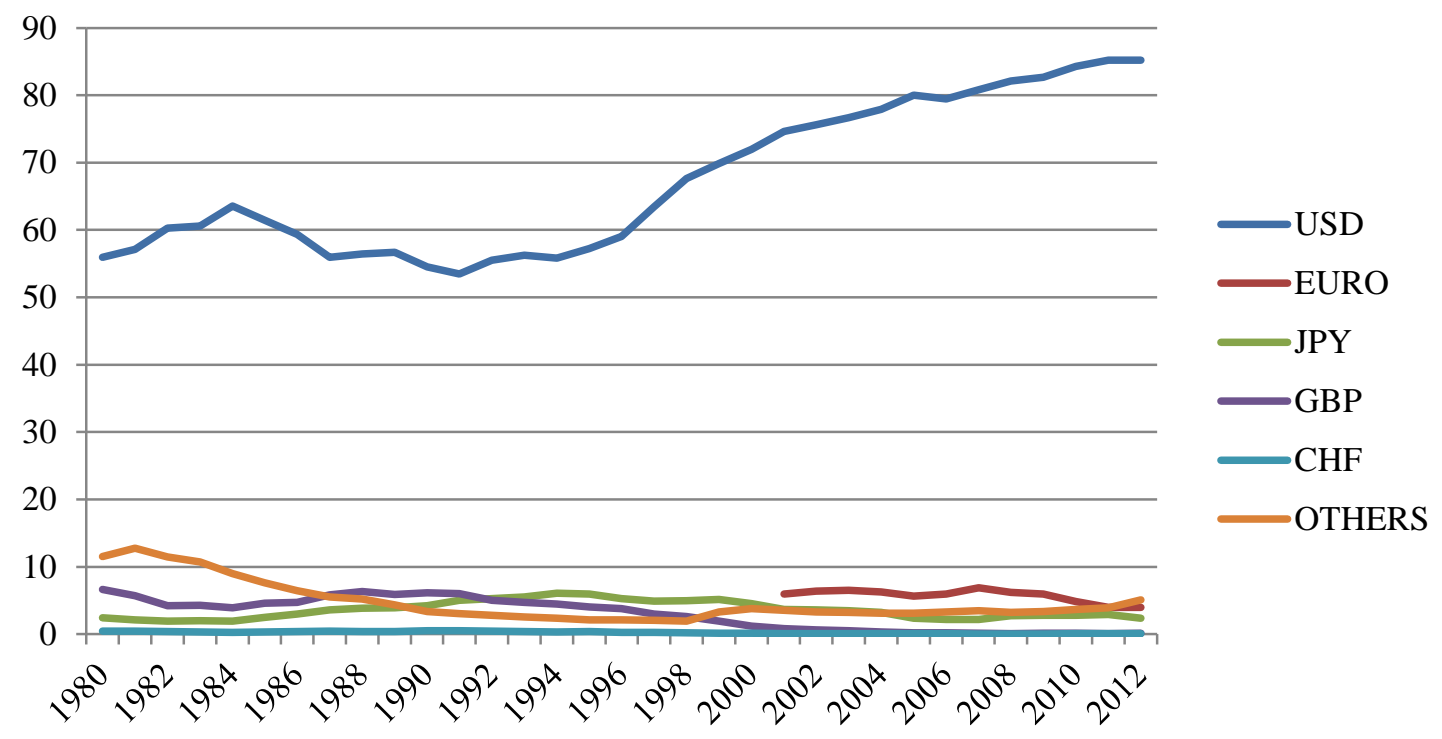


Figure 2. Regional average PPG share by denominating currency (\%) E. Middle East and North Africa

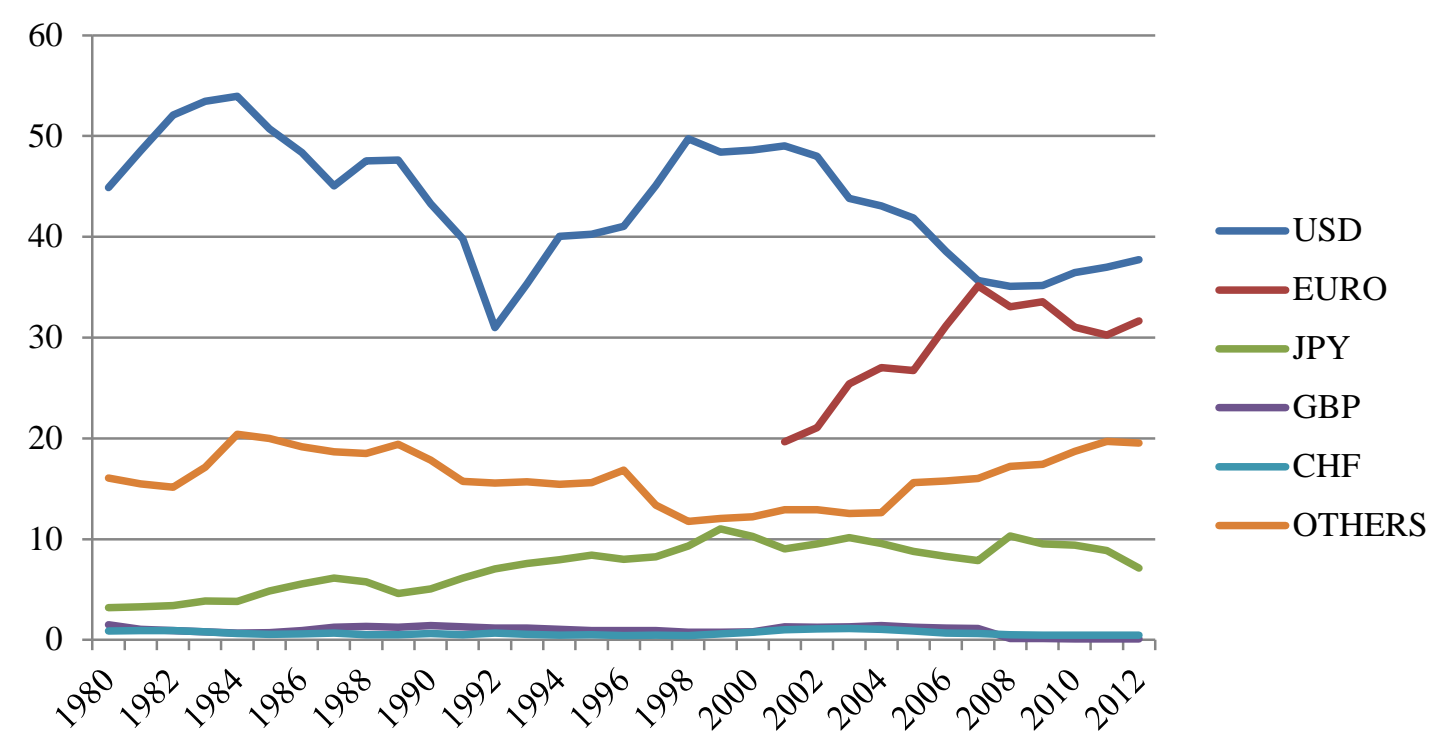

F. Sub-Saharan Africa

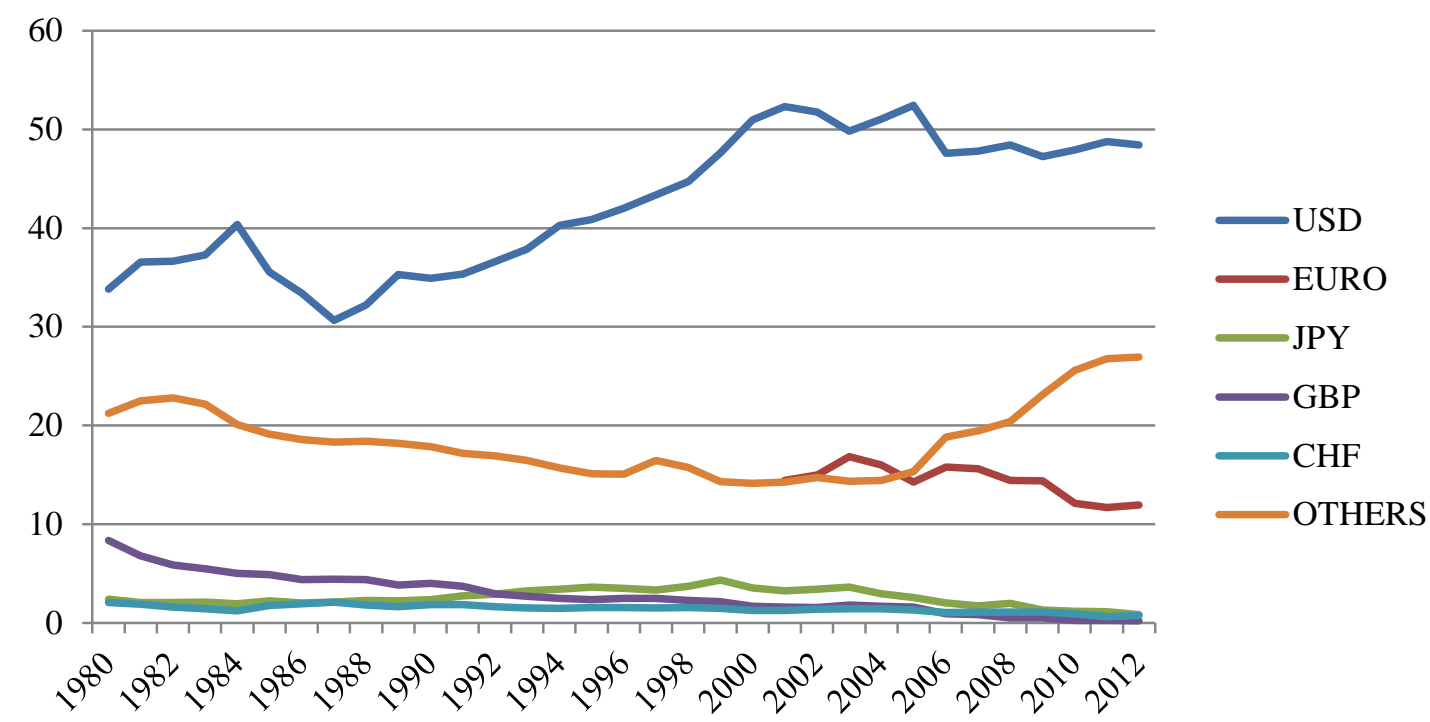


Figure 3. Average DEER-TREER correlations by country groups

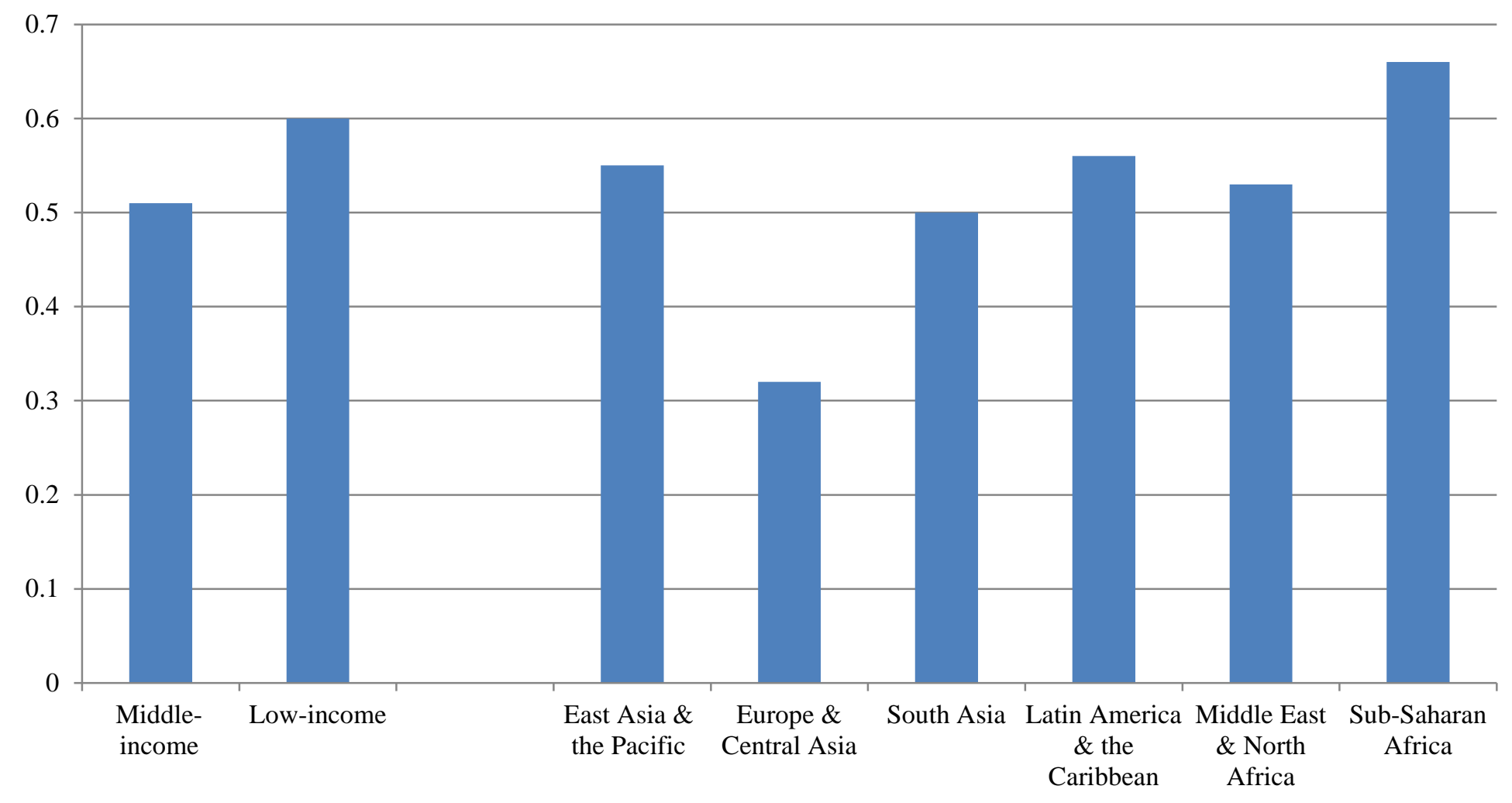

